\title{
Enterprise and economy
}

Cuts in public spending forced universities to devise schemes for selfhelp which would reduce their dependence on public money. Some academics murmured of 'going private', but it was seldom clear what they had in mind; perhaps they dreamed of some English parallel to Ivy League universities, small, select and well groomed, supported by massive fees and the donations of prosperous alumni (a body which the University of Manchester had hitherto failed to cultivate as a source of support).

The University was again forced to adopt a host of economy measures, some of them seemingly trivial, and puritans began to attack minor extravagances as grave lapses of discipline. On the other hand the University had to think of selling its services and of collaborating, not only with public institutions and Government departments, but also with industrial and commercial concerns. Its purpose in doing so was not just to raise money, but to demonstrate its usefulness to society and the economy, to win friends and restore itself to favour; it was important not to get involved in contract or consultancy work which would increase income but have no academic value, or produce results which might be used for intellectually dishonest or nefarious purposes. The University had to consider methods of increasing fee income, for example by pulling in the overseas students who were obliged to pay the full costs of their courses and had therefore become an important financial asset. Modular part-time degrees, enabling mature students to work at any pace they chose and accumulate the necessary credits over several years, would provide alternatives to the intensive courses which traditionally turned out young graduates. The Extra-Mural Department made ready to instruct almost everyone in the mysteries of computing, offering courses on 'The Micro and the GP', 'Packages for Dairy Farmers', 'Small Businesses and Micros' and so forth. More prosaically, it was vital to make University residences earn money all the year round, by accommodating conferences and even families on 
holiday, lest the property become unused plant, left empty and unprofitable for up to twenty weeks in every year.

Some economy campaigns, particularly the appeal to save electricity, raised echoes of the 1970s. Wiser now, the Communications Office designed no pin-ups, but hammered out the slogan 'Save Energy, Save Money, Save Jobs'; designed a surreal drawing of electric plugs and flexes strangling the campus; reminded everyone that the University spent $£ 2 \mathrm{~m}$. a year on energy; and issued admonitory stickers to be stuck on light switches. Helpful suggestions were made, which involved removing covers from fluorescent tubes to make them give more light and taking lifts out of service. Sticking plaster sealing the doors of one of the shafts to the south of the Arts Building served as a symbol of the new austerity.

But there were many reasons why consumption should increase, especially in science departments. New plants for liquid helium and liquid nitrogen had been installed in the Chemistry and Physics Buildings, and the Stopford Building was a constant drain on the University's resources. Not all news was bad; the Computer Board granted $£ 90,000$ towards the cost of electricity consumed in the Computer Building in 1982. However, the new Library extension increased the Library's bill by 332 per cent. When the University's engineers, as always, suspected the use of illicit electric fires, they were tartly advised by members of the Bursar's Department that the electric typewriters and word processors spreading through the Main Building were more likely to be the culprits, and these machines could hardly be outlawed. Halls of Residence, which could plead no such excuses, had for a time a bad record, and it was never easy to persuade them to save.

Incentives and methods were much discussed. Make departments and buildings pay their own bills, or let them be credited with a proportion of any savings they made. Convert oil-fired boilers to coal, at high initial cost but with some prospect of long-term economies. There was little evidence that huge savings would be possible, for consumers soon became blasé and careless, and, as Harry Cameron has put it, great 'sourness and worry' sprang from the cuts falling on 'a massive campus'. University engineers could never in conscience abstain from doing things vital to safety, such as maintaining the substations. The Building Committee was empowered to shut down a building if the need arose.

Minutiae bulked large and extravagance on stationery and postage was condemned. Economy envelopes must be used for all internal communications, fine white ones were banned, and all but the most 
urgent outside letters must go by second-class post. This regime had the disadvantage that when envelopes all became equally unprepossessing they ceased to offer clues as to the importance of their contents. Hence many academics, finding administrative chores doubly distasteful in the threatening climate, were tempted to consign them unopened to the wastepaper bin. An ill-worded directive advised: 'There is little point in sending a thesis by registered mail as this service is designed primarily for objects of some value.' One meeting of the Arts Faculty became obsessed, to its Dean's exasperation, with the royal blue carpet being laid outside the door of the Council Chamber - dispense with carpets, proclaimed one speaker after another, and there would be more jobs for lecturers. Some nostrils flared angrily at the smell of fresh paint in the Stopford Building; its decoration, at a cost of a quarter of a million pounds, did not seem justifiable in the midst of financial crisis. Mr Crosby, the Director of Building Services, assured critics that the painters had switched from a five-year to a seven-year cycle. Years of deepening dinginess, however, could lead to poor morale as well as damaging the fabric. 'It's all so dirty!' cried a fastidious young woman up for interview in the Arts Building one Wednesday afternoon. No doubt she took her custom elsewhere.

Social events, any suggestion of pomp or frivolity, became candidates for the guillotine. Their abolition, however, would be bad for public relations. On 5 May 1982 the Queen came to open the new Library Extension (which had been in operation for several months) and, as had her mother in 1951, received a copy of H.B. Charlton's Portrait of a University, now a memorial to a vanished world. Hers was the first visit to the University by a reigning sovereign, but not everyone was impressed. A disloyal subject in the Bursar's Department suggested that Ms Diana Dors or Dame Edna Everage, who had at least written books, would have done the job 'just as nicely and at a fraction of the cost'. The officers of the Students' Union became confused. The Executive wanted to invite Her Majesty by letter to cancel her visit and, as the University's Visitor, to inquire 'as to the University's future intentions as regards the Library'; but some dissenters thought that, as professed republicans, they could not do so, because their letter would implicitly recognise the Queen as Head of State. The royal visit went ahead, unchallenged.

Two University journals disappeared from circulation. Staff Comment was now twenty years old and had been in the 1960s a lively grumbling magazine, publishing the splendid 'Letters of Lemuel', a Swiftian satire on the University. But it had been flagging for some 
time and failing to attract the three editors, one from Arts, one from Science and one from UMIST, who were thought desirable. Its humour had become forced, its journalism earnest, its readership increasingly bored. A bacteriologist called it a waste of time and taxpayers' money. A member of the Government Department exhorted: 'Set a good example, end production of your appalling comic. Its continued existence is a monument to ecological savagery and puerile inanity.' Thirty-eight correspondents wrote in the journal's favour, but their support was not enough to save it. It had lost some of its thunder to Communication, the features magazine of the Communications Office. This too was to go.

There was, however, more need to justify the University's decisions and report its achievements than ever before. The task fell to This Week, the cheaply produced house magazine, which took on some of the duties of the defunct journals. It explained the University's position on most matters and expounded the complexities of its finances with as light a touch as possible. Sometimes, as its mood swung from gloomy to cheery, it was taxed with unseemly jocularity. Correspondents accused it of playing down the parlous state of the Library, of reporting the Vice-Chancellor's remarks at Senate but not those of the opposition, and on one occasion of insensitive gloating over the gains made by a controversial sale of valuable books. But it was prepared to publish correspondence criticising the University's policies and to provide a forum, as Staff Comment had done, for complaints about inadequate parking arrangements, the malfunctioning of the telephone system, or the University's failure to cover the cost of running the Senior Common Room and provide it with portering and window cleaning. The convention that creditable news should appear in This Week and scandal in Mancunion (not always strictly adhered to) served the community reasonably well.

Could the University, in hard times, continue to subsidise institutions such as the Whitworth Art Gallery, the Manchester Museum, the University Theatre and the University Press, or should they be treated as ballast which could be thrown out to increase the buoyancy of the balloon? All of them enhanced the University's reputation, and the Press carried the University's name abroad. Although it had committed the offence of losing money, it could claim to be the third largest university press in the country and one of the oldest. Defenders of the arts argued that the UGC had allowed for all these institutions when calculating the unit costs for Manchester students - as Professor Cox explains it, 'you'd give more for a student at Manchester than you did 
at Hull, because Manchester has to support an art gallery, it has to support a museum ... and it's got the University Press, it's also got departments which are far more expensive, like Medicine, it's a very complicated argument. But the point is that we discovered that the University Press's staff were included in the baseline charges.' The argument saved the Press from the threat of immediate closure, but Senate agreed that the Press and other institutions should be 'brought nearer to a self-financing status'.

It was understood that the University would cease to fund the Press's overdraft by the end of the session 1983-84, although it would still act as a guarantor. In 1983 Council delegated the management of the Press to a newly established Press Board, chaired by a lay member of Council. Their minds no doubt concentrated by the threat of being hanged in a year or two, the Press organised two large academic book sales at bargain prices to clear their warehouses, the first in Manchester and the second in Liverpool, to which they transported five tons of books. They strove to increase their share of the market and received small boosts from such events as the award of the Nobel Prize for Literature in 1982 to Gabriel Garcia Marquez - for the Press had sole British rights to the publication of his work in Spanish, and had recently brought out the novella No-One Writes to the Colonel in their Spanish texts series for school and university students in Britain. Reports in the financial years 1982-83 and 1983-84 both alluded to a brisk improvement in sales turnover and, by 1984, to net profits of just over $£ 50,000$. Books such as The Industrial Archaeology of the North-West, by Owen Ashmore, the retiring Professor of Extra-Mural Studies, helped the Press to improve its sales record. Works of local history, treatises on such subjects as the Great Bridgewater Canal, promised to sell, and so did the modestly priced Family Tree Detective, a handbook for amateur genealogists. The number of new titles increased from about seventy per annum in the mid-1980s to between ninety and one hundred by 1988 , when the Press had a thousand titles in print and was publishing five scholarly journals. In the words of Francis Brooke, who became Publisher in 1988, 'It would be in nobody's interest for the Press to be a private publishing company for members of the academic staff'. The Press was not to be suspected of acting as a kind of school magazine, unduly willing to publish the turgid and unappealing works of Manchester scholars.

Early in 1982, the professional youth theatre company, Contact, which had long been the principal user of the University Theatre, offered to take over both the theatre itself and the Brickhouse, so long 
as the company succeeded in negotiating larger grants from the Arts and Greater Manchester Councils. Although the University agreed to this proposal in substance, it retained responsibility for the Theatre building; continued both to subsidise it to the tune of $£ 25,000$ per annum and to perform certain financial services free of charge; and nominated some members of the Council of Management. It seemed important to distribute theatre time equitably between the professional company, University departments, and University amateurs. In May 1982 the Arts Faculty objected to the failure of Council and its committees to consult academic bodies before making decisions with academic consequences, for the number of weeks assigned to University use would fall from twelve to six and those allowed to modern language departments from three to one, so that they could no longer contemplate putting on plays in French, German or Spanish. By July the modern language departments had won their case and the real losers were the amateurs. Rendered homeless, the Stage Society for members of the University staff turned into a company of strolling players and took its productions to the Renold Theatre at UMIST, to the Library Theatre in central Manchester, and to the Grange Arts Theatre in Oldham. In November 1983 the Society put on Murder in the Cathedral in the church of the Holy Name. When in March 1985 it presented Edna O'Brien's Virginia at the Edgar Wood Centre in Daisy Bank Road, a member consoled himself with the possibility that its nomadic existence might bring it back to 'something near its original function - the production of plays of highly intellectual and specialised interest which offer a fairly unique experience to University actors and audience alike'. Hard times, these remarks implied, were not always harmful to culture.

Reginald Dodwell, the Director of the Whitworth Art Gallery, was an energetic fund-raiser who sought corporate sponsorship to counter the effects of the cuts. In the 1980s he raised money to establish the Bistro (an agreeable eating place which increased the charms of the Gallery), and to open a Wallpapers Study Room and a Paper Conservation Studio. Neither the Art Gallery nor the Museum could bolster its fortunes by charging admission fees, but money could be made by putting temptation in the way of visitors. By the autumn of 1984 souvenir shops selling tasteful artefacts, as in an English country house open to tourists, had opened in the Museum and the Gallery, whilst a form of Wendy house stocking similar wares appeared in the concourse below the Senior Common Room in the Refectory building where students sat on benches to eat their lunchtime sandwiches. 
Memorabilia of most kinds - ties, T-shirts, scarves, tobacco-jars, umbrellas, almost any object capable of bearing the emblem of the University - could be purchased here, and much Christmas shopping done on the premises. Its motto, like that of the county of Rutland, might well have been 'multum in parvo'. From these upmarket campus shops, so This Week reminded its readers, customers could bear away 'art books, original terracotta sculptures, and handmade glass and porcelain ... Someone, somewhere, right now, is probably drinking to our health from a set of monogrammed crystal glasses and matching decanter.' The souvenir trade took a new turn with the invention in 1984 of another money-spinner, graduation videos. Purchasers of these items would be able to view at their leisure a display of University pomp and ceremony lasting twenty-five minutes, made personal to them by inserting a close-up, lasting about one minute, showing them receiving their degrees. The University might not be a business, but business could be done on University premises.

Mancunion once quoted a dictum of Carlyle: 'The true university of these days is a collection of books.' In the 1980s, however, the Library did not command universal respect, let alone recognition as the University's core. Most faculties had agreed that, as a service provided to the whole institution, it should enjoy some protection against the full force of the cuts, but this view was not unanimous. It had difficulty in meeting demands, if only because in the recent past emphasis had fallen on the acquisition of stock rather than the recruitment of staff, and the cuts were now diminishing a labour force already too small and strained. Certain things, as Diana Leitch remembers, contributed to a sense that the Library was letting down one of the University's most powerful faculties: the absence, from 1981 to 1986, of a Medical Librarian after the early retirement of David Cook; the disappearance, with the move of the Medical Library into the Main Library, of the comfortable Medical Reading Room; the conviction that the wrong books were being bought - no more were they sent on approval by Haigh and Hochland, the University booksellers, for consultants to inspect before purchase.

To some users and occupants the new building was convenient and spacious - 'there was a lot of water in the walls, and it was cool ... we spent a lot of money on the air conditioning in the first few years. And we hadn't many computers in, so we didn't have static in the atmosphere', as Pat Cummings remembers. Other aspects of the Library's architecture and decor earned it little affection, particularly the charmless entrance hall which resembled in some users' eyes the 
concourse of a London railway station and offered no immediate encounter with the staff. A graduate student commented on 'the absurdity of having a luxurious library without the means to run it properly' - smart surroundings had made the shortcomings of the overstretched services all the more glaring. Critics disparaged the Library as 'a drain on resources, the Printed Book Emporium'.

The UGC knew that universities might be tempted to solve financial problems by cutting libraries, and advised against the move, making the University a special grant of $£ 314,000$ in 1982 to help with services and the upkeep of premises. But it soon proved necessary to suspend a number of periodical subscriptions, since the rising cost of learned journals threatened to eat up more and more of the acquisitions budget, and it seemed essential to reduce their share from 46 to 40 per cent of the whole. Faculties had to recommend further economies in 1984-85 and to shave up to 10 per cent off their allocations. How could British libraries and British scholarship continue to compete with their prosperous American counterparts?

Even in these unpromising circumstances some progress was possible through resort to automation, especially by extending the use of information technology in order to compile, acquire and search bibliographical databases. Michael Pegg, who had served at an army organisation attached to NATO, said: 'I want to encourage information work.' Diana Leitch, who held degrees in science from Edinburgh and had begun her career by compiling World Textile Abstracts at the Shirley Institute in Didsbury, joined with Alan Neville in establishing a new Science and Medical Information Unit. ' . . . in a little room, where you couldn't swing a cat round, we had two computers, and we actually were involved in the first ever scientific information searching, both printed and electronic, in this Library'. 'We were the first people to go with one of the big international database hosts, STN International, in 1983 . . In 1985, we took on board CDRoms . . . And by 1987, Alan had worked out how to do what's called "A Local Area Network" . . ' By October 1984, the Library was announcing, Soviet-style, a Five Year Plan for making the greatest possible use of information technology, the Librarian proclaiming at a seminar that 'Any major library which fails to automate is condemned to becoming a backwater.' It was a far cry from the days when cataloguers had filled out index cards with steel nibs, and when the introduction of fountain pens had been regarded as a startling innovation.

No library had enough copies of course books and recommended articles to satisfy student demand; students had, or claimed to have, 
little money to buy books; and the success of many seminars depended on all students having read the same material by the same time. One solution appeared to lie in the zealous use of the photocopying machine, to make vital articles and extracts available in departmental libraries, or even provide handy anthologies of vital texts for students to possess. However, some of these measures led to illicit photocopying so flagrant as to attract the attention of the Publishers' Association, which was probably tipped off from within the University, for many academics were concerned about the effect on their own royalties of unchecked pirating. The law allowed a student or scholar to acquire one copy of an article from a non-profitmaking library for his or her personal use, but it did not permit a course organiser to produce numerous booklets assembling other people's material without seeking permission. Feeling the pinch as much as anyone else, the Association threatened to take legal action against the University for condoningif not encouraging breaches of copyright. In May 1984 the Association agreed not to sue, but insisted that the University enforce strict observance of the Copyright Act. Let warning notices appear on all machines and all illicitly copied material be surrendered to the Association (some departmental libraries were sorely depleted). Let it be understood that 'Multiple copies (e.g. class sets) of copyright material may not be made without prior permission and payment may have to be made.' Eventually, in 1987, it proved possible to agree on an experimental scheme which would license institutions to make multiple as well as single copies for teaching purposes, on designated machines, at a fee of so much per page, without going through the cumbersome process of seeking permission in advance.

Students were quick to complain of deteriorating services, which were not confined to libraries and classrooms. Their welfare, no longer sacrosanct, was falling victim to the overriding claims of economy. The Student Health Service maintained by the University and UMIST cost the institutions $£ 210,000$ a year and became a candidate for rationalisation in 1980-81, even before the heaviest cuts descended. Unlike most such centres, it was not funded by the National Health Service except to give advice on contraception, and it was not recognised as a general practice. The student service operated from nine to five on weekdays, but did not provide emergency cover outside those hours and was not entitled to supply medication for long stretches of time. Its special function was to advise students on problems closely connected with their way of life, of which ordinary GPs sometimes showed little understanding. These included not only the notorious examination 
stress, the students' occupational disease, but also matters connected with sexual behaviour and experiments with illegal drugs.

Mancunion asserted in February 1981 that over the last seven years the number of consultations each year had increased from 26,000 to 60,000 . But were students suffering from ordinary afflictions using the Centre because it was convenient and approachable, when they could easily have applied to a local GP? Was it right that the University, hard pressed to make economies, should pay its specialised health centre to copy the functions of the National Health Service? University strategy was to reduce expenditure by some 25 per cent and to urge students to register with GPs. Students feared they would encounter difficulties as thousands of extra patients began besieging doctors' surgeries in Rusholme, Fallowfield, Chorlton and Withington. The suppression of doctors', nurses' and counsellors' posts in the student service proved to be a lasting grievance, reiterated throughout the decade. Campaigners protested that even before the cuts, when four full-time doctors and three part-timers had been catering for the 16,000 students of Owens and UMIST, provision had fallen far short of a recommendation made in 1979 by the Royal College of Physicians - to the effect that there ought in University practices to be one full-time doctor to every 1,500 students.

Income generation was the only counter to dismal cost-cutting. Home students who cost the country money were regarded with a wary eye, but overseas students, who paid the full cost of their tuition, could be seen as a financial asset. They accounted in November 1981 for $£ 2 \mathrm{~m}$. of the $£ 60 \mathrm{~m}$. of the University's income. All universities feared that the fees imposed by the Government would drive students away from the United Kingdom in search of better bargains elsewhere. The proportion of overseas full-time students in the University of Manchester did indeed fall from 9.4 per cent in 1980-81 to about 7 per cent in 1982-83, and remained at much the same level in subsequent years; faculties were urged to aim at 10 per cent. By autumn 1981 the Malaysian Government had decided that British fees were too high and Malaysian students almost disappeared from the scene, with recruitment to Mechanical Engineering and to Education declining especially sharply. Universities now had reason to regard overseas students as trophies, and, as Ken Kitchen recalls, they became increasingly reluctant to share recruiting secrets with each other. By February 1983 Manchester was dropping behind in the race, outstripped by universities as varied as Cambridge, Kent and Lancaster. It would be necessary to bombard promising areas with seductive publicity; to 
offer daily allowances to induce Manchester scholars visiting overseas institutions to stay on long enough to beat a drum for the University; to reward departments which overshot their allotted targets.

It was important that standards should not lapse; student journalists had warned that racial tension might arise in the University if it did favours to rich overseas students in order to boost income, and connived at the practice of treating education as a saleable commodity. The financial gains made from overseas students increased the moral obligation to understand their difficulties and provide for their needs, though the Students' Union at intervals reproved the University for not doing enough to help. Their intellectual and social success depended on a reasonable knowledge of English. Kenneth James was the pioneer of the TEFL [Teaching English as a Foreign Language] unit, and succeeded in devising some instructive entertainments, the Inspector Thackeray plays, whose fame spread beyond Manchester when they were published by Longmans as 'structural readers' and recorded on cassettes. Each piece contained three clues, 'one obvious, one less so and one hidden - in order to test comprehension and maintain interest'.

Development of part-time, continuing, post-experience and adult education was not only a public service but a defence against the argument that, as the numbers of young people fell, universities would become underemployed and could with justice be cut. Arthur Armitage had begun to explore the field in the late 1970s. Recommendations of working parties led to the establishment in 1983-84 of a Board for Part-time Education and the appointment of a Director to supervise from on high the part-time degree courses offered by departments. The first Chairman of the new Board was an enthusiast, Sam Moore, who had started his own career as a part-time degree student before the Robbins expansion and the Open University had pushed part-time undergraduates into the shade. The first Director was Keith Drake, a Senior Lecturer in Education with degrees in History and Economics who had taught in schools in Liverpool and Newcastle-under-Lyne and in the Extra-Mural Department of Liverpool University. Before long his brief was extended to include continuing education and training, a term which referred to the task of bringing professional people and others up to date with new developments in their fields rather than to the mounting of degree courses.

Part-time undergraduate degrees depended on accumulating credits over a number of years by taking, at one's own pace, courses on several different levels, from basic to advanced, which were known as 
modules and commanded a fee of $£ 100$ each. It was a little like the process of earning a Sunday School Bible by the ticket system in Tom Sawyer, but more sophisticated and a good deal less haphazard. Students could, if practical, attend the ordinary courses during the day, or go to classes specially provided for them in the evening (evening students, regrettably, had a restricted choice of subjects, since not all lectures and tutorials could be repeated out of normal hours). Ten credits added up to an unclassified ordinary degree, thirteen to a classified honours degree. Some students could content themselves with a few credits and stop short of graduating. All could, as a psychologist commented, avoid the "sudden death" syndrome encountered by students examined during temporary life crises'.

The new Board approved the first courses in 1984, with a view to admitting the first students in October 1985. Enthusiasm for parttime teaching varied between different parts of the university. Apart from Nursing Education and Nursing Studies, science and technology were not represented in the first batch of part-time degree courses, which were offered by nineteen academic departments spread across five faculties: the others were in Adult and Community Education, American Studies, Economic and Social Studies, Education, History, History of Art, Language Teaching, Literary Studies, and Theology. Scientists and engineers, however, would perhaps be better equipped to provide refresher courses to industrialists and professional or business people eager to be brought up to date.

One of the University's less intellectual tasks was to obtain the greatest possible benefit from its student premises by opening them up to the conference trade. This aim was not new, but the crisis of the 1980 s created a pressing need to find new customers. Since the University was not itself a business, it was tempted to hand over some of the work to a firm well versed in catering for profit. At issue was the student village at Owens Park, equipped with three restaurants, rooms for 900 guests and meeting space for 650. This was expected to earn about half the University's annual income from conferences. By the early 1980s it was in need of refurbishment and its residents, conscious of shrinking grants, were pressing for a 'pay-as-you-eat' scheme, so that they would no longer have to contract to buy more meals than they were likely to consume and more than they could afford. Since its foundation in 1964 the running of Owens Park had depended on a division of labour between managers, who were responsible for food and fabric, and tutors, who were in charge of pastoral care. In the late 1970s the system had not worked impeccably, 
and few managers had lasted long in post: some, bent on ditching unprofitable activities, antagonised the Owens Park Students Association (OPSA). Close a dining-room to students on a term-time Sunday to accommodate a conference of flower-growers, and a manager could expect to make some money but also arouse disproportionate resentment for apparently putting commercial considerations before student needs.

In the summer of 1982 tension mounted when the University Council contemplated farming out catering and cleaning at Owens Park to Grand Metropolitan Hotels Ltd., which already catered at the Business School and at Broomcroft Hall in Didsbury (the residence for Simon Fellows and other academic visitors to the University). Grandmet would use two of the three existing dining-rooms to run a non-profit-making 'pay-as-you-eat' scheme and would see to the cleaning in return for a management fee paid out of Owens Park funds. It would derive its profit from a half-share with the University in the net conference income from Owens Park and from the surplus on the running of the bar, whilst OPSA would receive a half-share of 'the surplus arising from the gaming machines'. Council heard representations to the effect that 'University conference business generally was not realising its full potential', and that the 'marketing strengths and international links' of Grandmet would introduce the University not only to new kinds of conference business but also to 'the "package tour" trade which the North West was so anxious to promote'.

This vision of holidaymakers enjoying Owens Park was seductive to those who had to solve its financial problems. But the students and staff questioned the intentions of a firm which, or so they believed, would cut jobs to increase profits (up to 140 might be at risk). The University officers argued that, since Owens Park was too generously staffed, redundancies were inevitable, and that Grandmet, which had 'numerous operations within a small radius of Fallowfield', was better equipped than the University itself to re-employ staff. Students, however, believed that Grandmet would raise prices, close dining rooms to students, and turn over Owens Park, even during term, to the profitable conference trade. Some members of Council were perturbed at the news that Grandmet had originally been invited to advise on the problems of Owens Park, but had then, by offering to do the job themselves, become interested parties rather than independent consultants. None the less the University officers had chosen to back Grandmet's scheme and put no other proposals forward; by holding no competition they had lost one of the advantages of venturing into 
the market. Should Grandmet withdraw from the arrangement after the first five years and take its business elsewhere, the University would in the end lose conference trade.

Owens Park staff took umbrage when the proposals appeared in a circular and were not explained to them face to face at a meeting; the Bursar subsequently agreed to talk to them after they had refused to hold any converse with Grandmet. Two campus unions, NUPE and NALGO, called a strike of Owens Park workers on 2 June 1982. One week later, almost a thousand members of NUPE assembled outside the Main Building and, like an outsize chorus, provided a lively setting for a contentious meeting of the University Council. A petition bearing a thousand signatures reached the Chairman of Council at the end of the discussion, which had lasted three and a half hours. With libellous gusto but no evidence, the student press hinted at corruption in high places: had some University officer been offered a directorship of Grandmet, in which the University held shares? Council chose not to refer the proposals back for further consideration, but did decide to approve the principle of 'pay-as-you-eat' and to empower the officers to negotiate further over the summer.

Within the next month, two other companies, Gardner Merchant and Taylorplan Catering, made proposals, but the trade unions representing staff at Owens Park worked out a scheme which would enable the University to retain direct control of the catering with their collaboration. 'Pay-as-you-eat' would come in gradually over the next academical year and the unions accepted the inevitability of some job losses. This being so, the case for privatising the catering, with all the resentment such a move would provoke, became less compelling. It was, in any case, not clear that the conference trade, unaided by private enterprise, was producing disappointing results; on the contrary, This Week was beginning to boast about its resilience and reporting that income in 1981-82 had exceeded that of the previous session by 26 per cent. Acting in partnership with Greater Manchester Council, the University was attracting large international conferences to the city and had succeeded in booking seven such events, which were due to take place within the next three years. Thousands of delegates would surely attend gatherings interested in Latin America, science education, the education of the deaf, pure and applied chemistry, and microbiology. If the University itself had no lecture theatre vast enough to accommodate the plenary sessions, then the Palace Theatre up the road, accustomed as it was to Christmas pantomimes and touring musicals, could be pressed into service. So, it later transpired, 
could the Free Trade Hall, where Princess Anne opened the Fourteenth International Congress of Microbiology in September 1986.

At the end of October 1983, the branch secretary of NUPE, commenting on the University's rising conference income, declared that 'Privatisation can be beaten with common sense and close working between management and the trade unions.' Student interests were more clearly safeguarded by the appointment of a resident Warden for Owens Park, who now replaced the non-resident Chairman of Tutors; the post went in October 1982 to Dr R.R. Frost, a Senior Lecturer in Botany who had considerable experience of Owens Park. By May 1983 it seemed clear that some gains from conference revenue were being used to keep the fees and rents from University accommodation down to levels more closely related to the modest increases of 4 per cent in student grants. About twenty jobs had gone from Owens Park in 1982-83; the Owens Park fee was to rise by only 2.8 per cent in 1983-84.

Other halls of residence succeeded in attracting much conference business. Woolton Hall's rooms were spacious and it raised plenty of revenue during vacations. It was true that self-catering flats now sheltered more students than did Owens Park and the traditional halls, and that, having no dining halls and few public rooms, they were illequipped to house conferences. But the glossy bulletin of the University Conference Office, which began to appear in 1984, did not confine its praise to the 'mouth-watering meals' which Woolton and Langdale, Ashburne and Hulme would offer to peckish delegates. It also extolled the virtues of self-catering flats, which would provide a base for families on holiday to visit, for example, the Liverpool International Garden Festival. As the cradle and coffin of the Industrial Revolution, Manchester might not in itself seem an attractive resort. But it was possible to take an 'Industrial Heritage package holiday' at modest cost, and some organisations had historical, if not sentimental, reasons for arranging their gatherings in the city. Indeed, the Boilermakers' Union, founded in Manchester in 1834, deserted the seaside, returned to the city to celebrate their 150th anniversary, and put up at Owens Park in 1984.

Although the University undertook little new building during the 1980s, it did resolve in 1984 to build a new sports and conference complex, which was eventually named the Armitage Centre in honour of the late Vice-Chancellor. This was to rise on the site of some shale tennis courts at the athletic grounds in Fallowfield and cost about $£ 950,000$. A grant from the Hulme Trust, University money earmarked 
for the improvement of student amenities, would provide $£ 400,000$, and the rest would proceed from an interest-free loan to be repaid over a period of thirty-five years from the income of the Centre as a venue for conferences and exhibitions. In prospect were, not only a gymnasium, an aerobics room and a climbing wall for aspiring mountaineers, but also a main hall capable of accommodating an audience of 1,000 on 'tiered, upholstered seating'. This could be removed when the auditorium was called upon to house exhibitions or provide courts for badminton players.

Student representatives on Council welcomed the plans but grumbled at the probability that the Centre would be used for conferences during term. They disliked the near-certainty that all customers, including students, would have to pay more to use the Armitage Centre than to use the older McDougall Centre close to the main site of the University on Oxford Road. On the eve of the opening, on 1 December 1986, Mancunion conceded that 'All in all, Manchester students have no longer got a reason to gripe about their sporting facilities.' In October 1987, however, they found the Centre closed for sport and monopolised by three major exhibitions; the manager explained that the Centre had been running at a loss, and that the University was pressing him to make it pay.

Exploiting intellectual property was as important as making full use of real estate. During the 1980s the University attempted to go into business on its own account by means of a new holding company, and it also set out to invite certain kinds of enterprise - high-tech firms which would directly benefit from scientific expertise - to become neighbours of the University and settle on land close to the Education Precinct. Sceptics wondered whether, in the early years, the University would earn anything more than pin-money from these ventures, which would require heavy investment and provide no instant solutions to financial problems. But, by demonstrating the practical value of much University research and encouraging the inventors on its payroll, it might be possible to recover some of the approval which universities had once enjoyed in the sight of Government and society; to earn the enthusiastic support and perhaps the patronage of the business community which the Government extolled; and to join with the City in regenerating the area, not so much by reviving the old industries as by developing new forms of technology.

Some professors were lured away from the University, as Christopher Pogson, who had been Professor of Biochemistry since 1979, 'succumbed to the call of industry' and became Head of Biochemistry 
at the Wellcome Research Laboratories at Beckenham in Kent in 1984. Brian Robert Pullan (not to be confused with the author of this book) had been the first Professor in the newly created Department of Medical Biophysics in 1973 and had, among much else, worked with the radiologist Ian Isherwood on new techniques for diagnostic imaging, 'using the magnetic properties of certain naturally recurring atomic nuclei in the body'. As an appreciation of his work, put before Senate in 1983, explained, 'Brian Pullan has always been fascinated by the transfer of ideas into practice and has often been frustrated by the historical reluctance of British universities and industry to work together to this end. His work has done much to develop collaborative contacts between this University and industry. He has left to explore other ways of achieving the same goals and will still be working actively applying science and technology in medicine.' One might well ask whether the 'historical reluctance', so long deplored, could be overcome from within the University, and whether the crisis of the 1980s would at last provide the incentive to dispel it. Would Vuman, CURID and the Science Park become the signposts pointing to a new era of co-operation between the cloister and the factory?

The name Vuman (derived from 'Victoria University of Manchester') was supplied by the Registrar and the idea behind it came from the Bursar. In the 1950s, when Dr Beswick had been a lecturer in physiology, the departmental staff, led by their professor, had constructed their research apparatus with their own hands. Devices invented and made for particular experiments were discarded, but might well have had commercial potential if only the academic mind had been sufficiently aware of the possibilities. Aware of lost opportunities, Dr Beswick arranged for a search of university departments for ideas and devices which had been developed in the course of research and then laid aside. There was a strong possibility that some of these might be resurrected, that others might be added, and that old and new items might be developed commercially. In future, opportunities should not be missed and inventions should not be sold for less than they were worth.

Vuman was 'a holding company to facilitate the development of income-generating activities' and designed to 'provide the means for University resources and projects to be exploited commercially for the benefit of the University'. A public limited company devoted to the pursuit of commercial profits, it was established in October 1981 as a separate entity from the University (which was an educational charity). Although the Vice-Chancellor and Chairman of Council were appointed directors at the beginning of Vuman's career, they stepped 
down after a year to eliminate any possible confusion between their duties to Vuman and to the University. However, the holding company was able to make payments to the University by deed of covenant; to pay royalties to inventors or to their departments; to employ two members of the academic staff on secondment; and to retain the services of eleven others as consultants. For guidance it relied heavily on members of the University Council and sometimes on managers who had worked with or for them; Sir George Kenyon became Chairman of Vuman in 1982 on resigning his office as University Treasurer. The National Westminster Bank provided overdraft facilities of up to $£ 500,000$ to finance the new company's operations, and the firm of Paterson Zochonis lent it $£ 15,000$ per annum, free of interest, for three years. By November 1982 the company had an 'issued share capital' of $£ 200,000$ and an 'authorised share capital' of $£ 500,000$. By the summer of 1984 it was employing twenty-nine members of staff on its own account and in its subsidiary and related companies.

In its early days the company had four divisions, of which the first three were established during 1982. The computer division concentrated on selling Sirius computers, together with a word-processing programme for scientists, Vuwriter, which ran on these machines and was an invention of the Barclays Unit within the Department of Computer Science. The furniture division dealt in desks and tables designed in the Department of Town and Country Planning, which could be quickly assembled and dismantled on contractors' sites. It was the task of the laser and spectrometer division to manufacture and sell items designed in the Department of Physics. Vuman then proceeded to form a subsidiary company, Medeval, which had nothing to do with the Middle Ages but was devoted to the evaluation of medicines. It was to 'undertake investigations into the temporal course of medicine within the body (viz. its pharmacokinetics) in healthy volunteers', in the hope that the knowledge gained would 'be of benefit to patients by providing a better understanding of the mechanisms and effects of medicines'. Medeval's appeals for volunteers were to become a regular feature of This Week during the 1980s and provided opportunities for students to earn money, supplementing their meagre grants without overexerting themselves - in May 1985 Mancunion reported that students and other guinea pigs could be paid up to $£ 350$, according to the amount of 'inconvenience' they suffered (it was never suggested that they were exposed to risk).

By July 1984 the furniture division was destined for closure, since its commercial prospects did not justify allocating further resources, but 
others had been established and the variety and complexity of the operations were growing. A Vuman robot had emerged from the combined expertise of three lecturers, in Pharmacy, Mechanical Engineering and Computer Science. There was now a liquid crystals division; an industrial control division which used a computer to watch over industrial processes; and a project which set out to 'analyse the vibration characteristics of machinery as an aid to design and preventive maintenance'. Medeval and Vuman Computer Systems Ltd. now ranked as subsidiary and associated companies, as did another entity, Visual Machines Ltd., which was producing 'image recognition systems based on research carried out in the University's Department of Medical Biophysics'. Yet another company joined Vuman's empire in 1985, a commercial operation for the teaching of English as a foreign language which had grown out of the Faculty of Education; this bore the name of Delta, which stood for 'Direct English Language Teaching Agency'.

In the first full year of trading, 1982-83, Vuman reported a net profit of nearly $£ 67,000$ on a turnover of almost $£ 750,000$. A turnover of more than $£ 1 \mathrm{~m}$. was forecast for 1983-84, but Senate heard warnings that development expenditure would very likely reduce the profits in the current year. The question of how much more capital should be poured into Vuman was to exercise Council at intervals throughout the 1980s. As Sir George Kenyon has commented, 'Vuman is a useful thing, but very long-term ... . it takes ten years to develop a new product, or to develop a new idea, to get it making money commercially.'

Planned in 1982-83 and opened in 1984, the Science Park was a collection of buildings and offices concentrated near the University. As the Bursar later put it, just as chemical reactions are produced by molecules bumping together, scientific progress may be advanced by people bumping together. The project did not involve establishing entrepreneurs in offices on the University site, but the principle was that 'they could use our facilities, and they could talk about this and that to the professors of this and that ... the idea was to get the board room into the Senate, and we were going to turn the Christie Building into a club, and it was going to cost a million quid, but they jibbed at that'. A promising site lay close to hand, off Lloyd Street and near the back of the University Library. Some City councillors, however, appeared to dislike the University as an 'elite' institution and responded coldly to the idea of opening up the land for development. But Professor Dennis Welland and the Bursar succeeded, by a mixture of charm and persuasive argument, in convincing the one councillor who was beginning 
to appreciate the power of the Science Park to create jobs for the City: the University, they insisted, would not just be pursuing its own ends, but would make its own resources available to companies which need not have originated in the University. At the next meeting of the City planning committee the University's ally won over a sufficient number of his colleagues and they succeeded in pushing the proposal through the whole Council.

The arrangement eventually made was that the City would lease the site for 125 years to a Science Park Company run by a board of fifteen directors. Although all higher academic institutions in the area would be involved, only the University and UMIST would invest in the Company, together with the City and some established firms. Thirtyfive per cent of the shares would go to the University and it would appoint at least three directors (it chose the Bursar; the Treasurer, Ronald Brierley; and a solicitor, Dennis Westbrook, who was a member of the University Council). UMIST would have the chance, should it so desire, to buy 23 per cent of the University's holding, and when it in fact exercised this option F.M. Burdekin, Professor of Civil and Structural Engineering, represented UMIST on the board. The first building on the site was to be a so-called 'incubator unit' intended mainly for small developing companies and confined to those 'operating in genuine high technology fields'. One might well hope that the proximity of such things would 'greatly improve the transfer of University-developed technology into industry', and perhaps members of the University staff would obtain consultancies and earn suitable fees. Perhaps, too, the firms would wish to use the laboratories, equipment, workshops and conference facilities, computers, libraries and information services which lay close to hand, and the University would be able to charge them for the privilege.

First to move into the first building, named Enterprise House and officially opened by the Duchess of Kent in December 1984, were Visual Machines Ltd., an associate of Vuman (which held 25.4 per cent of the shares in it), and Thinking Software. On their heels came the European branch of the Advanced Technology Resources Corporation, and Textile Computer Systems Ltd. The scheme owed much to the vision and influence of a well-known Manchester solicitor, Robin Skelton, who was convinced of the enormous potential of 'high-tech' enterprises. He died in August 1988, and the second building in the Park, opened a year after his death, was named after him. Skelton House originally accommodated Medeval, one of Vuman's companies, together with the National Occupational Hygiene Service, CIM 
Microdynamics, and the Colgate-Palmolive Dental Health Unit.

Soon to join them in the Park was a third University enterprise, known as CURID, the Centre for Urban and Regional Industrial Development. Its first director was to be the geographer Peter Lloyd, an expert on industry and employment in the region who was anxious not only to study but also to encourage small businesses. Floated by a grant of $£ 100,000$ from one of the clearing banks, by another of $£ 45,000$ from the Manpower Services Commission, and by several other grants, CURID's object was to compile and relate to each other two storehouses of information. One database would list the research interests of companies in the North West, and the other the academic and research resources in the area which might prove of interest to those firms. It was hoped that CURID might persuade some firms to take up residence in the Science Park. The process followed the same principles, and pursued much the same aims, as the Research Consultancy Service of the 1970s and its newsletter, Contact.

One of the brightest novels of the 1980s, David Lodge's Nice Work, was both a campus and an industrial novel, a reincarnation of Mrs Gaskell's North and South, a dialogue between the managing director of an engineering firm and a budding lecturer in English literature. 'Is money the only criterion?' 'I don't know a better one.' 'What about happiness?' Some thirty years earlier, Princess Elizabeth had charmed an Oxford audience by calling the universities 'a powerful fortress against the tide of sloth, ignorance and materialism'. It was doubtful whether, in Margaret Thatcher's England, universities could resist materialism, in so far as it meant the call to contribute to the country's economic regeneration; doubtful, too, whether they could avoid being taxed with sloth unless they manifestly resorted to self-help.

Weary of endless talk of income generation and savings targets, many academics inquired plaintively how far and why the University was supposed to have become a business. It was undoubtedly expected to remain solvent and to respect employment law, and it was happy enough to accept endowments from business enterprises; Barclays Bank was reproved by students for its connections with South Africa, but it had financed a chair in Microprocessor Applications in Industry which the University did not hesitate to accept. Partnerships with industry, sociable relations, sharing of resources and discussions of common problems all seemed desirable, though the student press questioned the ability of science parks and high technology enterprises to create employment on a large scale - were they not designing 
machines to eliminate the need for human labour? It was vital that the University should not, for the sake of making money or demonstrating its usefulness, become the slave of capitalism or the servant of the Ministry of Defence; but something might be gained from dialogue with business enterprises, and from making businesspeople aware of the inventions which stood in need of commercial development. It was clear that the University could not live by economies alone. Nor should it, like the small provincial university in Malcolm Bradbury's novella Cuts, devote itself with indecent enthusiasm to cutting, privatising and seeking sponsorship at almost any cost. 